\title{
The Application of Multimedia Technology in Aerobics Teaching in Colleges and Universities
}

\author{
Chao Fan \\ Xi'an Physical Education University, Xi'an, Shaanxi , 710068, China
}

Keywords: Multimedia technology; Teaching; Aerobics; Application strategy

\begin{abstract}
With the development of science and technology and the progress of society, multimedia technology has been widely used in the teaching of aerobics in colleges and universities. Multimedia teaching is of great significance to establish aerobics complete, correct action concept, help students to accurately master the technical movements, highlight the focus of teaching, breakthrough teaching difficulty, improve students' interest in learning and correct the mistakes. Based on the author's learning and practical experience, this paper firstly analyzed the multimedia technology on aerobics teaching, and then put forward measures to improve the aerobics teaching effect in colleges and universities by using multimedia technology. This paper argued that in order to promote the application of multimedia in the teaching of aerobics in universities, we need to attach great importance to strengthen the thinking in software and hardware facilities; moreover, we should pay attention to combine with the traditional teaching mode and communication between teachers and students, so as to improve the comprehensive quality of aerobics teachers in colleges and universities.
\end{abstract}

\section{Introduction}

With the development of science and technology and social progress, the multimedia technology has been widely applied in aerobics teaching in colleges and universities. We should combine organically the multimedia technology with aerobics teaching in college and universities. The commonly completing mode of task was more and more widely used in teaching practice. In the application of multimedia technology in the teaching of aerobics in colleges and universities, we can better accomplish the teaching goals and improve teaching quality and teaching effect. This paper firstly analyzed the multimedia teaching and the characteristics of teaching of aerobics, and then discussed the teaching situation of college aerobics and the superiority of the use of multimedia technology in the teaching of colleges and universities. Further, the paper discussed the use of multimedia technology on improving the effect of aerobics teaching and then put forward the corresponding countermeasures.

\section{The Significance of Multimedia Technology on Aerobics Teaching}

It helps to establish a complete and correct concept of action. Multimedia teaching can help teachers understand and analyze the textbook, and unify the technical specifications of teaching materials. In addition, we can vividly display the whole aerobics movement through multimedia technology. Next, the slow motion with complex skill of presentation can clearly show the aerobics movement and routine methods in detail. On this basis, combined with the teacher's direct demonstration and explanation, students can get a deeper impression on the action combined with the teaching method of "complete individual to complete". As a result, students store the complete, clear and specific image in their brain under the "relative real" visual scene so that to establish correct motor imagery. Finally, the action is more standardized and integrated, so that students master the technical essentials.

It helps students grasp the difficulty and key point of the action. The forms of aerobics movement are complex, and most of aerobics are done in an instant. It is difficult to analyze the 
standardization degree of action with the eyes. Putting some of the best technical action and routine with multimedia presentations in the classroom for students is not only making vivid, intuitive and clear impression, but also seizing the key link, taking the replay, broadcasting in fast or slow speed, adopting freeze techniques to display. This will be very beneficial for students to master the technical essentials and the details. In addition, teachers often encounter difficulties on demonstration in the practical teaching, and the movement is not easy to describe and express. It is hard for students to understand the changes of actions, the opportunity of movement and experience on process. At this movement, the multimedia technology can fully display its skills.

It is conducive to individual learning in teaching. In multimedia technology, there are many individual learning software designed according to different characteristics of teaching. This software is suitable for different students, and can create conditions for the students' individual learning. Moreover, students can decide the learning time, learning place and learning progress according to the needs of their own learning. When students learn through multimedia technology, teachers can guide the implementation according to the specific situation of students, so that to promote students' learning efficiency. This is conducive to the further development of individual learning in teaching.

It can enrich the college aerobics teaching mode. The teaching mode can enrich the teaching mode by applying multimedia technology in the teaching of aerobics in colleges and universities. According to the theories of learning, we can create different learning conditions and learning environment by means of the multimedia technology and virtual reality technology, so that to enrich the college aerobics teaching mode. For example, we can create the desired learning context and interactive learning environment by applying multimedia technology in the teaching of aerobics in colleges and universities according to the constructivism learning theory. Moreover, we can promote learners' active meaning construction to carry out inquiry learning.

It can improve the aerobics teaching quality and teaching effect in colleges and universities. Aerobics teaching in colleges and universities through the use of multimedia technology can transfer a large amount of information within a very short time in learning, make convenient acquisition and reading for student information, so that to meet the students of aerobics related knowledge needs. In addition, the multimedia technology also can mobilize the students of various senses, so that to make it easier for students to accept knowledge and understanding. Especially the use of multimedia technology in teaching software design applied to teaching practice can get good teaching effect, and can improve the aerobics teaching quality and teaching effect in colleges and universities.

\section{The Measures to Improve the Effect of Aerobics Teaching in Colleges and Universities with the Help of Multimedia Technology}

Think highly on thoughts. In order to improve the aerobics teaching effect in colleges and universities, the first thought is to be highly valued through applying multimedia technology. The teaching file made provisions on the application of multimedia technology in the teaching. It has very significant meaning for us to change the traditional teaching methods, update teaching concepts and improve the effect of aerobics teaching in colleges and universities. At the same time, the use of multimedia technology in teaching is an educator needed to conscientiously fulfill the obligations of aerobics in colleges and universities. Therefore, we need to seriously comprehend the essence and connotation of applying multimedia technology in the teaching practice, and the teaching plan should be combined with the characteristics of aerobics teaching in colleges and universities to formulate the use of multimedia technology. At the same time, we should pay attention to the teaching practice of change, and attach importance to the development of new materials, promote the organic combination of multimedia technology and college aerobics teaching and cultivate students' ability of practice and innovation.

Strengthen the software and hardware facilities. In order to use multimedia technology in the teaching of aerobics in colleges and universities, we must strengthen the software and hardware facilities. In general, strengthening the software and hardware facilities in the specific measures 
include the following: increase the construction of multimedia technology funding for aerobics teaching in colleges and universities to provide funding by using multimedia technology; strengthen the computer maintenance and management, so that to ensure the orderly development of multimedia teaching; Pay attention to the aerobics teaching software of the university purchasing work, so that to enrich the content of classroom teaching and arouse students' learning interest and learning enthusiasm; strengthen the development of college aerobics teaching software so that to reflect their own teaching ideas and teaching style; Establish a database of university aerobics teaching to enrich teaching resources; establish of aerobics teaching in colleges and universities website to promote the college aerobics teaching information exchange and sharing of teaching resources.

Pay attention to its combination with the traditional teaching mode. We should pay attention to combining with the traditional teaching mode in the process of applying the multimedia technology to college aerobics teaching. Multimedia technology is an advanced teaching method to improve the traditional teaching mode, but it can not completely replace the traditional teaching method. Therefore, in university aerobics teaching, teachers should pay more attention to the combination of multimedia technology and traditional teaching mode. In the process of displaying aerobics exercises by multimedia technology, teachers also need to explain and guide the use of language, so that to give full play to their respective advantages. Moreover, they should also combine the multimedia technology and traditional teaching method organically, so that to complement each other and commonly serve to improve the effect of aerobics teaching in colleges and universities.

Pay attention to the communication between teachers and students. When we launch aerobics teaching in college by means of multimedia technology, multimedia is a bridge of communication and interaction between teachers and students. However, in order to improve the teaching effect and teaching quality, relying on the multimedia technology is not enough. Because the multimedia technology will not automatically improve the learning efficiency. Multimedia technology is just an assisted mean to improve the teaching. The learning efficiency and the teaching effect mainly depend on the joint efforts between teachers and students. In the process of teaching, teachers is the key role and they should give full play to the function of multimedia. Therefore, when the aerobics teaching in colleges and universities need to change the traditional teaching concept in the use of multimedia technology, and make reasonable design of the teaching content; moreover, they should adhere to the students as the main body so that to avoid adhering of the multimedia as the main body in teaching practice. Further, they should also pay attention to communication and interaction between students and teachers, so that to maximize the effectiveness of multimedia technology in the teaching of aerobics in colleges and universities.

Improve comprehensive quality of the aerobics teachers in colleges and universities. Time has given the university aerobics teachers higher requirements. In the face of the trend that multimedia technology has been applied to college aerobics teaching, teachers need to improve their comprehensive quality, reinforce the ability of the use of multimedia technology to strengthen their own learning and training, and constantly enhance their knowledge structure to adapt to the changing times and the needs of teaching. On the one hand, aerobics teachers in colleges and universities should strengthen the ability of multimedia learning and mastering of multimedia technology. For some teachers, the multimedia courseware is a new test; therefore, the university aerobics teachers need to strengthen the technology of multimedia learning and mastering the skills of multimedia. Moreover, they should effectively combine the music, video and image, so that to launch aerobics teaching in colleges and universities. In addition, the teacher can also make some aerobics teaching software to reflect their own teaching ideas and teaching style. On the other hand, the university aerobics teachers should further change the traditional teaching concepts, improve teaching method, optimize teaching content and apply multimedia technology into college aerobics teaching, so that to improve the teaching quality and teaching effect. 


\section{Summary}

With the rapid development of science and technology, the multimedia teaching is the inevitable trend of development. It brought a new teaching mode for aerobics teaching. This model is a dynamic system and a bilateral activity of teaching and learning It is also the communication between teachers and students, and common development of the interactive process. The aerobics teaching mode under this new concept has injected new vitality to the development of aerobics and brings great changes to the aerobics teaching. Aerobics teachers should keep pace with the times, renew the idea, give full play to the role of multimedia and innovative teaching mode, so that to mobilize the enthusiasm of the students. As a result, the students are willingly to learn and regard study as a pleasure so that to optimize the aerobics teaching and improve the teaching effect of special purpose.

\section{References}

[1] Zhang Xiao. Explore the Technology of Multimedia in Aerobics Teaching in Colleges and Universities[J]. Chinese and Foreign Entrepreneurs, 2014, (18): 144-145.

[2] Zheng Liping, Guo Changli, Guan Li. Discussion of Application of Multimedia Technology in College Aerobics Teaching[J]. Journal of Chengde Medical College, 2014, (04): 443-444.

[3] Dong Xinjun, Zhang Yuxiu. Inquiry Teaching in the Experimental Study in College Aerobics Teaching[J]. Journal of Nanjing Sport Institute (Social Science Edition), 2012, (01): 104-108.

[4] Zhang Yuanyan. The Use of Multimedia in the Teaching of Dance in Colleges and Universities[J]. Yiyuan, 2009, (09): 54-55.

[5] Zhai Xiuzhen. Application of Multimedia Technology in the Teaching of Calisthenics[J]. Journal of Luoyang Normal University, 2008, (05): 153-155.

[6] Xiang Qun, Zhou Jianshe, Tan Chengqing. Body Language in the Practice of Teaching in College Aerobics[J]. Journal of Shenyang Sport University, 2008, (01): 74-77. 